\title{
Tax Sparing
}

\author{
J. David B. Oliver, Coopers \& Lybrand, London; Visiting Professor of International Taxation, London School of Economics
}

Ever since tax sparing appeared in a treaty context for the first time in 1957, in a treaty negotiated between the United States and Pakistan, and the US Senate refused to ratify the treaty in its original form because of the inclusion of the tax-sparing provision, the United States has steadfastly opposed the inclusion of tax-sparing provisions in its treaties. Other countries have been more ambivalent. For exemption countries the issue presents itself less clearly because it takes a less provocative form. Either the income falls within the exemption anyway or, in other cases, there is simply a minimum rate or amount of taxation to which the overseas income should be subject in order to qualify for exemption; that level may by a treaty or by unilateral provisions be deemed to have been satisfied in the case of tax-spared income or profits. For credit countries, however, there is a much more obvious opportunity to pick up by way of taxation in the country of residence the tax saved by tax sparing in the overseas terrritory. Thus, the issue is more clearly presented as to whether the country of residence should grant a credit to match the tax spared in the overseas territory. This has led to a more equivocal approach by credit countries.

The question is not an easy one and can sometimes lead to an approach on the part of credit countries which borders on the patronizing. For example, it is sometimes said that tax sparing is an ineffective form of relief since the investment would be made with or without tax sparing and that the country of residence should feel free to tax the profits notwithstanding that tax has been spared by the source country.

A new study by the OECD ${ }^{1}$ offers a review of the current issues surrounding tax sparing and how the position has developed over recent years. Three features have clearly prompted the report. The first is the development in the economies of certain countries which now have a higher per capita income than some of the less developed Member countries and some of which are indeed themselves major sources of foreign direct investment. Singapore would be a prominent example. The second aspect is the enduring nature of treaty provisions. Thus, once tax-sparing provisions are included within a treaty they could last so long as the treaty runs. It is this feature which in other contexts may be said to have encouraged (i) an increasing use by the OECD of changes in the Commentary rather than the text of the Model to try to bring about variations in the meaning of the Model, and (ii) treaty override. Both of these habits stem from the difficulty, and time required, in seeking to renegotiate double tax treaties. The third aspect is an alleged increase in abuse of the provisions.

In the tax-sparing context the duration of taxsparing provisions has been tackled quite logically in practice by the introduction in recent years of so-called sunset clauses which ensure that the tax-sparing/ matching credit provisions only apply to profits arising over a limited period of time and/or themselves only have a limited duration and must then be renewed by extension or renogiation.

An element of the patronizing approach creeps into the Report with the statement that the large majority of OECD Member countries are of the view that the provision of tax sparing in treaties is not an effective way to promote foreign investment and to promote national economic goals.

'Investment decisions taken by international investors resident in credit countries are rarely dependent on or even influenced by the existence or absence of tax sparing provisions in treaties. This is supported by the experience of the international business community which encourages countries to conclude treaties regardless of whether tax sparing can be obtained.'

No direct authority for this comment is cited although there is a reference to the 1995 OECD Report, 'Taxation and Foreign Direct Investment. The Experience of the Economics in Transition'.

While there has indeed been a worldwide policy trend to broaden the base and reduce the rate, even the UK, one of the first to apply this policy, could slip backwards this year by introducing special incentives for the domestic film industry. There can be balancing factors, too, in a tax-sparing regime, irrespective of the extent to which investment is encouraged which would not otherwise take place. If, for example, a country

\section{Notes}

1 'Tax Sparing: A Reconsideration', Report by the Committee on Fiscal Affairs, 1998. 
chooses to introduce tax sparing for power projects then one result may be that some of the tenders for such a project are more competitive, i.e. lower. The tax foregone by the tax sparing is recouped, to some extent at least, by the lower price which the government has to pay for the project. For the residence country giving matching credit the result in a simple case is the same as if direct foreign aid has been given for the project.

The report indicates that some non-member countries are becoming concerned about concessions they have to make to obtain tax sparing when negotiating tax treaties. They may have to accept lower withholding tax rates or stricter permanent establishment rules. Thus, they have to forego additional revenue in order to ensure that their tax-sparing rules are fully effective. On the other hand, presumably if they did not have to make these concessions then they would collect additional tax at the expense of the countries of residence.

There is a tendency to discuss tax-sparing provisions as if they were uniform. In practice they can be broken down into different forms. They could be grouped into (i) the tax sparing of withholding taxes on dividends, interest and royalties, (ii) the provision of tax holidays for investments in a particular region or in particular projects, e.g. infrastructure projects or power projects, and (iii) other more general reliefs which may be on the basis of an industry. The report makes some recognition of this aspect in urging Member countries to consider whether tax incentives legislation is couched in such broad terms that the taxsparing credit should apply only to a more limited range of activities.

Happily, for those who believe in tax sparing (and matching credit), the report concludes that its analysis does not suggest that OECD and other countries which have traditionally granted tax sparing should necessarily cease to do so.

An interesting tailpiece is that, in its concern about abuse, the report contains in two annexes a write-up of two tax-avoidance schemes. Neither scheme was implemented: both were blocked by countermeasures. Perhaps in the next OECD report the Committee could include tax-avoidance schemes which do work? Now that would be a best seller. 